\title{
Part Per Trillion
}

National Cancer Institute

\section{Source}

National Cancer Institute. Part Per Trillion. NCI Thesaurus. Code C70566.

A unit of proportion equal to $10 \mathrm{E}-12$. 